\title{
Effect of Fertilization, Plant Spacing, and Season on Yield and Quality of Head Cabbage at Isabela, Puerto Rico ${ }^{1,2}$
}

\author{
Jaime E. Jordán Molero and Luis M. Cruz Pérez ${ }^{3}$ \\ ABSTRACT
}

\begin{abstract}
Four similar experiments were conducted at the Isabela Substation during 1972-73 to determine the effect of $\mathrm{N}, \mathrm{P}_{2} \mathrm{O}_{5}$ and $\mathrm{K}_{2} \mathrm{O}$ on the yields and quality of head-cabbage variety Hybrid Head Start. The experiments were conducted during the four seasons of the year. Two planting distances were also studied.

There was a tendency for maximum marketable yields with $\mathrm{N}$ applications of 0.2 units $(224.2 \mathrm{~kg} / \mathrm{ha})$ to 0.4 units $(448.4 \mathrm{~kg} / \mathrm{ha}) ; 0.8$ units of $\mathrm{P}_{2} \mathrm{O}_{5}(896.8$ $\mathrm{kg} / \mathrm{ha}$ ); and plant density of $71,700 / \mathrm{ha}$. There was no measurable response to $\mathrm{K}$ applications. Variations in applied N, P, or K did not affect solidity (firmness) of the heads.

Yield of marketable cabbage was somewhat higher in winter, but a reasonable production was obtained throughout the year in four experimental plantings.
\end{abstract}

\section{INTRODUCTION}

During fiscal year 1975-76 cabbage production in Puerto Rico was estimated at $2,720 \mathrm{t}$, with an average yield of $14.47 \mathrm{t} / \mathrm{ha}$, while the imports were estimated in 4,173 $\mathrm{t}(3)$. These figures point out the potential of increasing the area planted to satisfy local demand.

A profitable increase in cabbage production requires the substitution of improved techniques of production and better cultural practices, such as the correct use of fertilizers and plant populations during the appropriate season, for obsolete traditional farming methods.

Various authors have reported yield increase of head cabbage from $\mathrm{N}$ $(1,5,6), \mathrm{P}_{2} \mathrm{O}_{5}(1,7,11)$ and $\mathrm{K}(11)$ applications. Yield increase, as an effect of plant population increase, is mentioned by Webster (12). Halsey et al (4) found no significant difference in yield when distance between plants in the row was reduced.

\section{EXPERIMENTAL PROCEDURE}

A series of experiments was conducted to determine the effects of different levels of $\mathrm{N}, \mathrm{P}, \mathrm{K}$, and two planting distances on the yield and quality of Hybrid Head Start cabbage at all seasons of the year on a Coto

' Manuscript submitted to Editorial Board July 14, 1977.

${ }^{2}$ Part of a thesis submitted by the senior author in partial fulfillment of the requirements for the M.S. at the College of Agricultural Sciences of the University of Puerto Rico, Mayagüez Campus.

${ }^{3}$ Assistant Agronomist, Professor and Plant Physiologist, respectively, Agricultural Experiment Station and College of Agricultural Sciences, Mayagüez Campus, University of Puerto Rico, Río Piedras, P.R. 
clay soil, a Tropeptic Haplorthox, clayey, kaolinitic, isohyperthermic (9) at the Isabela substation. The substation is located on the northwestern part of the island at $128 \mathrm{~m}$ above sea level. Mean annual rainfall is 165.71 $\mathrm{cm}$, ranging from 8.00 in February to $20.68 \mathrm{~cm}$ in May. Average maximum and minimum temperatures are 29.42 and $18.87 \mathrm{C}$.

Experimental plantings were planned to coincide with the equinox and solstice dates. They were begun during June 1972 and finished during May 1973. Transplanting and harvesting dates, rainfall, and temperature registered during the experiments are summarized in table 1 .

Seedlings were grown in $35.5 \times 50.8 \mathrm{~cm}$ metal flats containing a uniform and sterilized mixture of sand, topsoil, and cured sugarcane filter-press

TABLE 1.-Transplanting and harvesting dates, temperature, and rainfall registered during the four experiments

\begin{tabular}{|c|c|c|c|c|c|c|}
\hline \multirow{2}{*}{$\begin{array}{c}\text { Planting } \\
\text { season }\end{array}$} & \multirow{2}{*}{$\begin{array}{c}\text { Transplanting } \\
\text { date }\end{array}$} & \multirow{2}{*}{$\begin{array}{l}\text { Average } \\
\text { length of } \\
\text { growing } \\
\text { season }\end{array}$} & \multicolumn{2}{|c|}{ Temperature } & & \multirow[b]{2}{*}{ Rainfall } \\
\hline & & & Maximum & Minimum & & \\
\hline & & Days & ${ }^{\circ} \mathrm{C}$ & ${ }^{\circ} \mathrm{C}$ & $\mathrm{Cm}$ & Days \\
\hline Summer & $6 / 21 / 72$ & 64 & 29.96 & 21.65 & 17.22 & 30 \\
\hline Autumn & $9 / 25 / 72$ & 57 & 28.76 & 19.50 & 38.99 & 25 \\
\hline Winter & $12 / 19 / 72$ & 58 & 27.88 & 18.47 & 10.80 & 15 \\
\hline Spring & $3 / 21 / 73$ & 64 & 29.31 & 19.24 & 18.90 & 18 \\
\hline
\end{tabular}

${ }^{1}$ Number of days between transplanting and second picking.

TABLE 2.-Characteristics of the soil used in the four experiments

\begin{tabular}{lcrrrrrrc}
\hline $\begin{array}{c}\text { Planting } \\
\text { season }\end{array}$ & $\mathrm{pH}$ & $\mathrm{N}$ & $\mathrm{P}$ & $\mathrm{K}$ & $\mathrm{Ca}$ & $\mathrm{Mg}$ & C.E.C. & $\begin{array}{c}\text { Organic } \\
\text { matter }\end{array}$ \\
\hline & & $\%$ & $P / m$ & $P / m$ & $P / m$ & $P / m$ & $M e q / 100 g$ & $\%$ \\
Summer & 5.00 & 0.21 & 3 & 80 & 950 & 188 & 9.00 & 3.36 \\
Autumn & 7.00 & .14 & 12 & 100 & 1581 & 181 & 7.35 & 2.85 \\
Winter & 7.30 & .23 & 19 & 118 & 1725 & 150 & 10.00 & 2.13 \\
Spring & 7.20 & .15 & 15 & 129 & 1413 & 126 & 8.70 & 2.76 \\
\hline
\end{tabular}

cake. They were kept under $40 \%$ shade with $\operatorname{Saran}^{4}$ cloth. One week before transplanting they were moved to full sunlight exposure for hardening. The plants were sprayed with a mixture of Dithane M-45 and Diazinon Ag500 for disease and insect control. In the last two experiments, Lannate was alternated with Diazinon due to a high incidence of the larvae of the diamondback moth (Plutella xylostella L.).

Soil samples were taken and analyzed prior to transplanting in each field (table 2). The soil site for the summer experiment was limed with $\mathrm{CaCO}_{3}$ at the rate of $4.48 \mathrm{t} / \mathrm{ha}$. The experimental plots were divided by

4 Trade names are used in this publication solely for the purpose of providing specific information. Mention of a trade name does not constitute a guarantee or warranty of equipment or materials by the Agricultural Experiment Station of the University of Puerto Rico or an endorsement over other equipment or materials not mentioned. 
15-cm wide ditches to prevent displacement of fertilizer between adjacent plots.

Each experiment consisted of 20 treatments having different levels of $\mathrm{N}, \mathrm{P}_{2} \mathrm{O}_{5}$, and $\mathrm{K}_{2} \mathrm{O}$, replicated four times, with two planting distances included in each fertilizer treatment. The experimental design was $4 \times 5$ rectangular lattice with split plots. The experimental plot measured 6.10 $\times 4.87 \mathrm{~m}$, with $6.10 \times 2.44 \mathrm{~m}$ subplots. Plant spacings were $60.96 \times 30.48$ cm (53,700 plants/ha) and $45.72 \times 30.48 \mathrm{~cm}(71,700$ plants/ha).

Fertilizer treatments were broadcast 2 days before transplanting and incorporated in the soil by hoe cultivation. Ammonium sulphate $(20.5 \%$ $\mathrm{N})$, triple superphosphate $\left(46 \% \mathrm{P}_{2} \mathrm{O}_{5}\right)$, and muriate of potash $\left(60.5 \% \mathrm{~K}_{2} \mathrm{O}\right)$ were used as sources of $\mathrm{N}, \mathrm{P}$, and $\mathrm{K}$. A blanket application of Esminel at the rate of $22.42 \mathrm{~kg} / \mathrm{ha}$ was made to avoid minor element deficiency.

Transplanting was done by hand. The field was treated with Dexon and Terraclor to prevent soil-borne diseases, and a bait of Dylox in cornmeal was applied to control soil insects.

For the control of weeds, Dacthal W-75 was used as a preemergent immediately after transplanting. This was followed by hand weedings as required. Overhead irrigation was applied whenever necessary. Each experiment was sprayed weekly, alternating Diazinon AG500 with Lannate for the control of insects. Dithane M-45 was used to prevent diseases.

In each of the four experiments, harvesting was done at weekly intervals beginning about 50 days after transplanting. Yield data were taken from the two center rows in each subplot. Production indices included marketable yield/ha, solidity, average weight of marketable heads, and the number of days between transplanting and harvesting dates. Heads weighing $454 \mathrm{~g}$ or more and having no appreciable blemishes were considered marketable. Solidity of the cabbage was determined by a modification of the method described by Pearson (10). It consisted of weighing individually a sample of six heads from each subplot and wrapping each in a polyethylene bag. Each cabbage was submerged in a 19-liter container filled with water. To this was attached an overflow pipe. Water displaced by the head flowed through this pipe and was collected and measured with a graduate cylinder. Solidity (firmness) was calculated by the water displaced per gram cabbage weight.

The following fertilizer-yield equation suggested by Capó (2) was fitted to the yield data:

$$
Y=\frac{A}{1+B(X-C)^{2}}
$$

where $X$ is the quantity of the fertilizer applied to the soil and $Y$ is the yield of the crop. In this equation $A, B$, and $C$ are parameters. $A$ represents the maximum yield obtainable in the given field with the 
optimum fertilizer application, $C$, under the prevalent climatic and other environmental conditions. $B$ is assumed to be an index of the variability of the crop yield as the quantity of the respective fertilizer material applied differs from the optimum application, $C$.
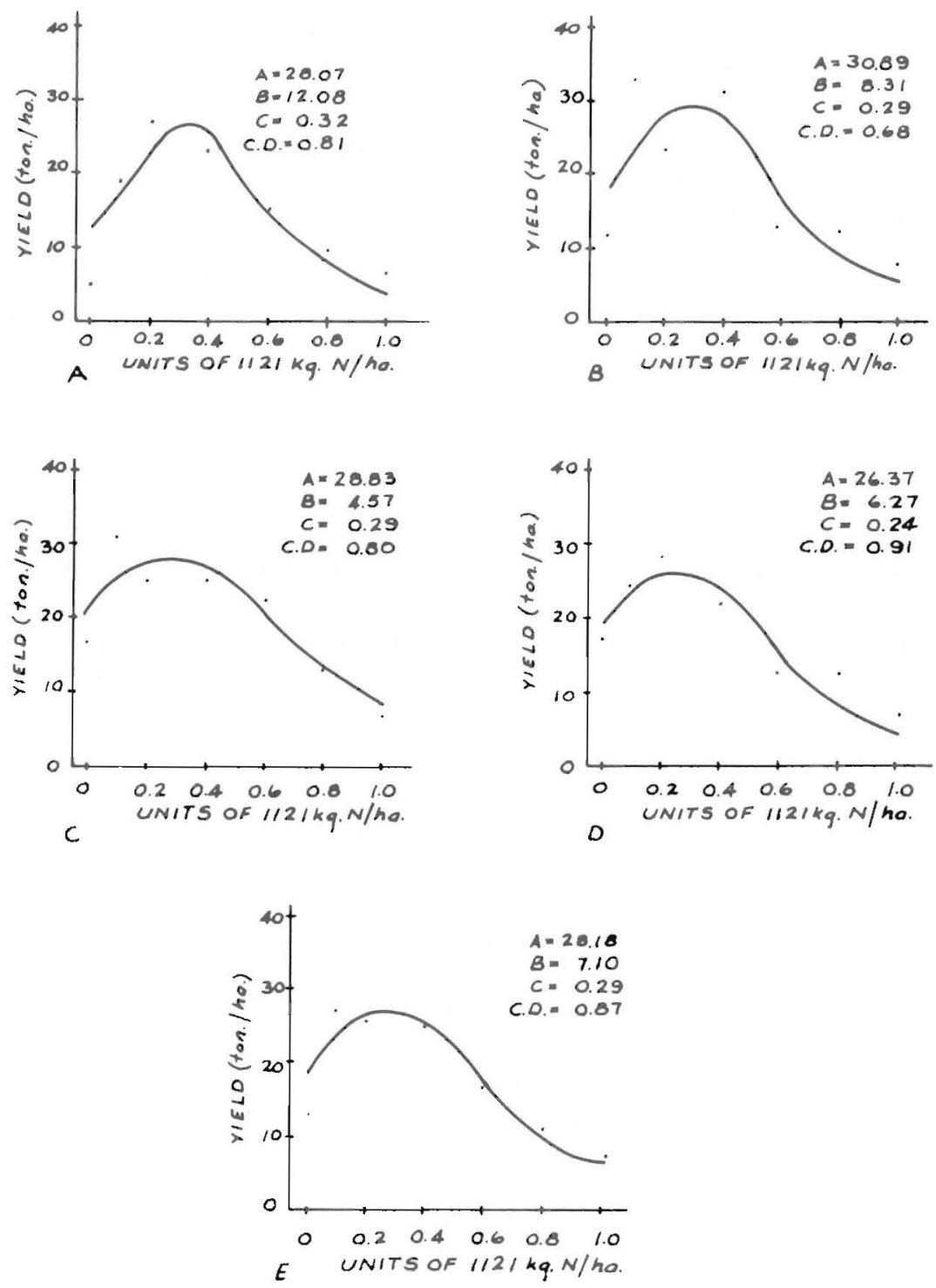

FIG. 1.-Nitrogen to cabbage yield relation during A, summer; $\mathrm{B}$, autumn: C, winter; D, spring; and $\mathrm{E}$, all experiments combined when planted $60.96 \times 30.48 \mathrm{~cm}$. 


\section{RESULTS AND DISCUSSION}

\section{PRODUCTION}

Marketable yield is shown in figures 1 through 5. The graphs also demonstrate the fit of the fertilizer-yield equation suggested by Capó (2).
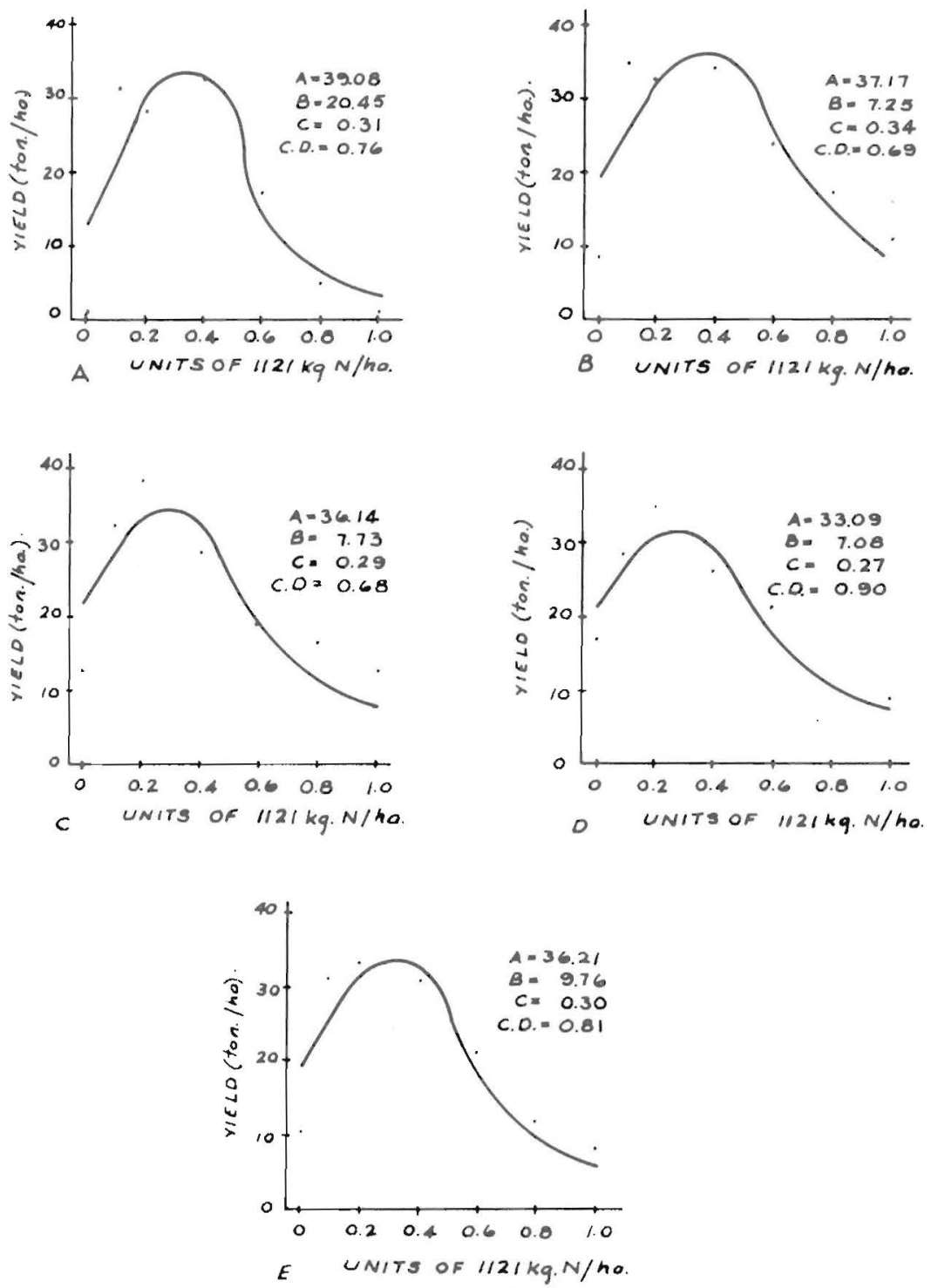

FIG. 2.-Nitrogen to cabbage yield relation during A, summer; B, autumn; C, winter; D, spring; and E, all experiments combined when planted $45.72 \times 30.48 \mathrm{~cm}$. 

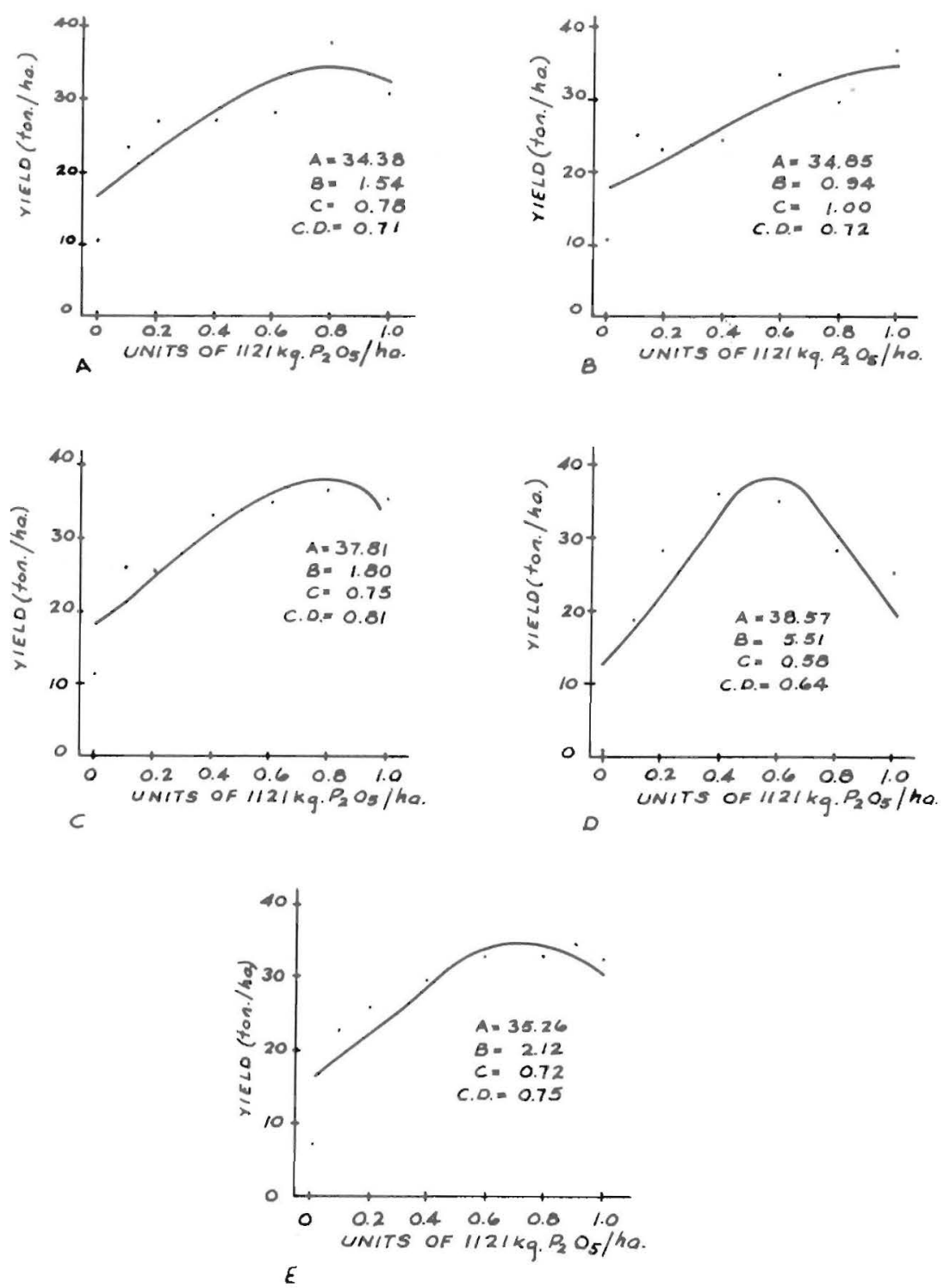

FIG. 3.-Phosphorus to cabbage yield relation during A, summer; B, autumn; C, winter; $\mathrm{D}$, spring; and $\mathrm{E}$, all experiments combined when planted $60.96 \times 30.48 \mathrm{~cm}$.

There was a tendency for maximum marketable yields to be obtained with $\mathrm{N}$ applications of $0.2(224.2 \mathrm{~kg} / \mathrm{ha})$ to $0.4(448.4 \mathrm{~kg} / \mathrm{ha})$ units at both plant populations and for yields to decrease with applicat on of more than 0.4 units ( $448.4 \mathrm{~kg} / \mathrm{ha}$ ) of $\mathrm{N}$. 
The detrimental effect of the high doses of $\mathrm{N}$ could have been an effect of the high concentration of ammonium sulphate in the soil or merely because of an ionic imbalance in the plant due to surplus of one element with low levels of the others.
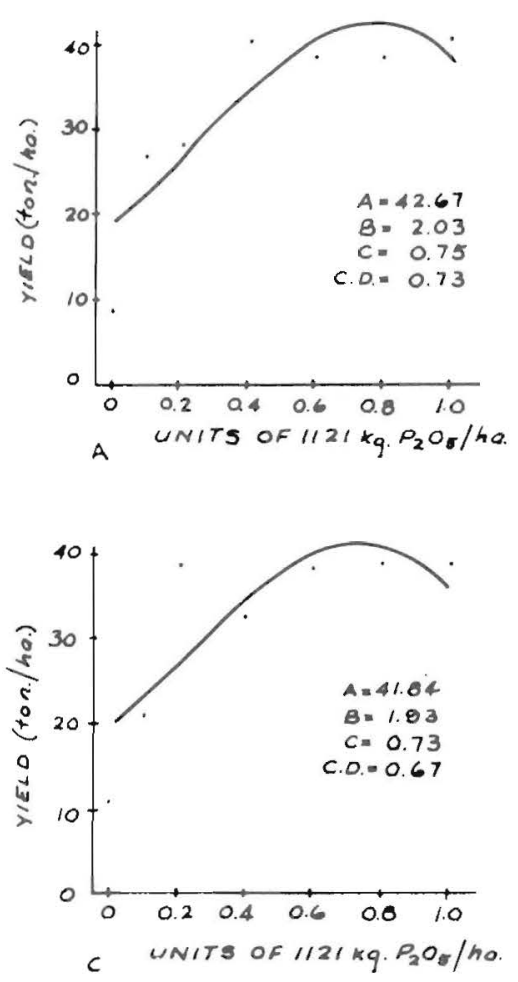
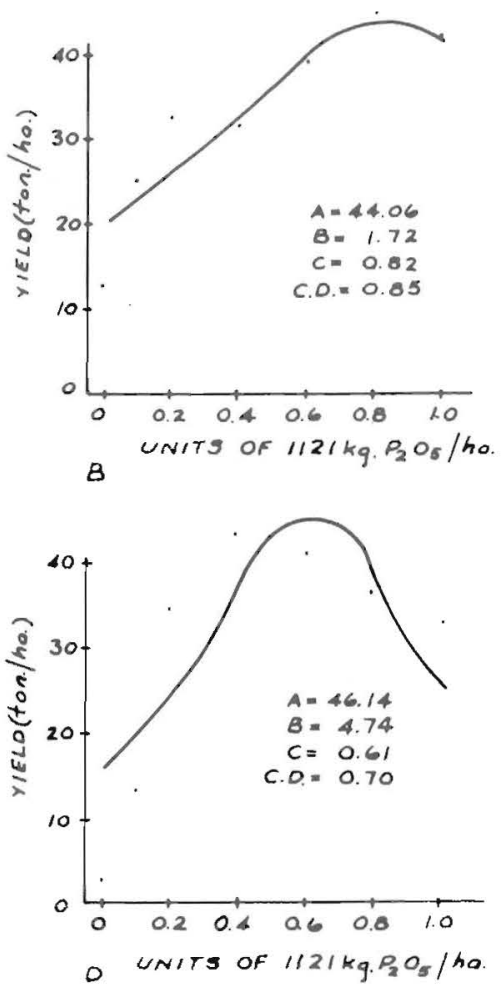

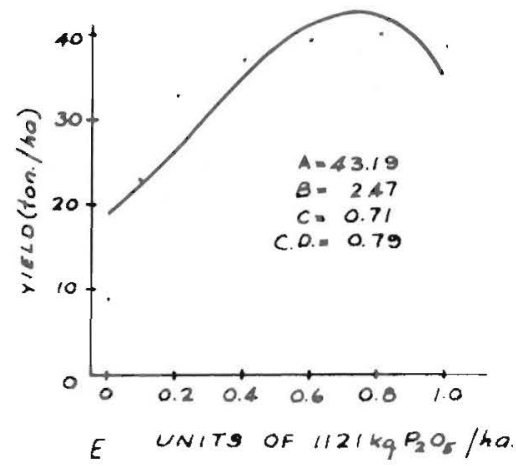

FIG. 4.-Phosphorus to cabbage yield relation during A, summer; $\mathrm{B}$, autumn; $\mathrm{C}$, winter; D. spring; and $\mathrm{E}$, all experiments combined when planted $45.72 \times 30.48 \mathrm{~cm}$. 

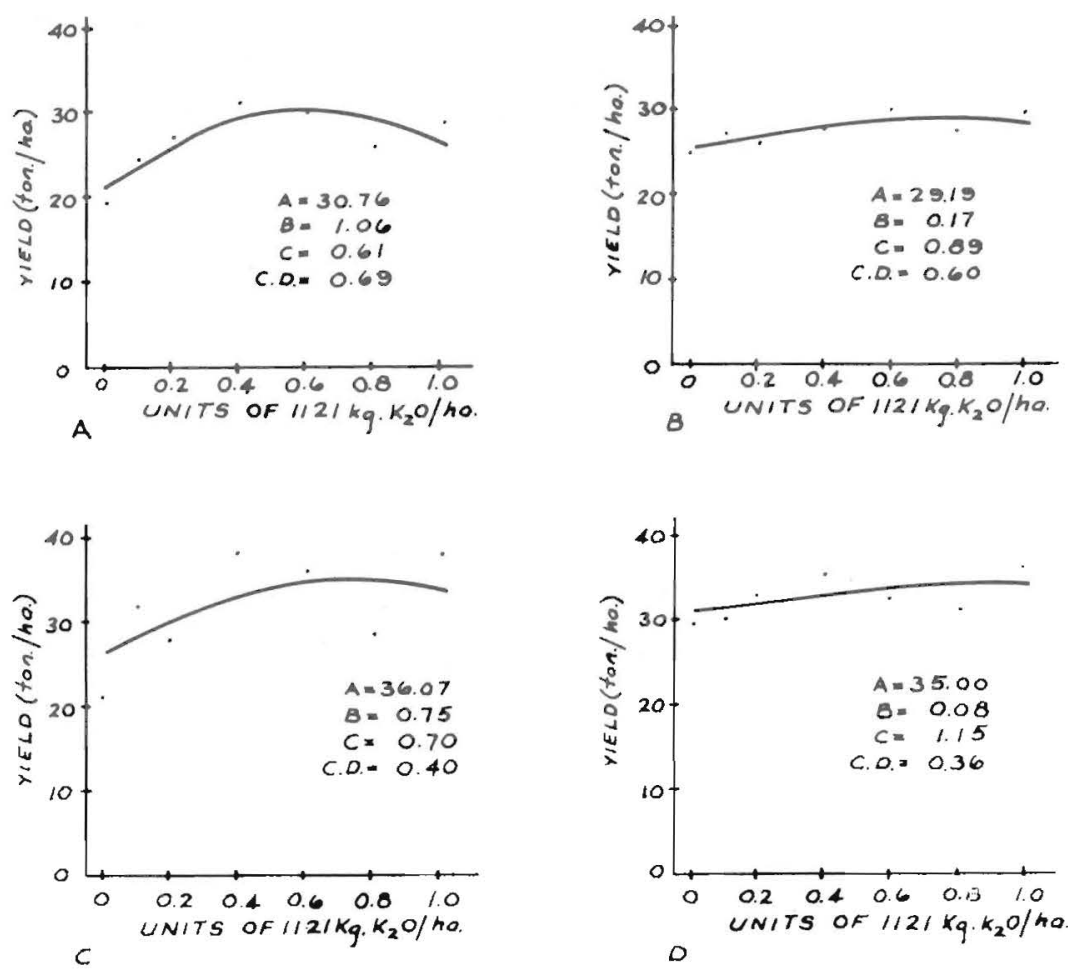

Frg. 5- - Potassium to cabbage yield relation during A, summer; $B$, all experiments combined when planted $60.96 \times 30.40 \mathrm{~cm}$; C, summer; and D, all experiments combined when planted $45.72 \times 30.48 \mathrm{~cm}$.

During spring there was no significant difference in yield in response to $\mathrm{N}$ applications. This suggests that there was more $\mathrm{N}$ available, as shown by higher yields of cabbage in the control plots as compared to yields during the summer experiments.

There was a marked response to phosphorus applications. A trend for maximum yields with $\mathrm{P}$ applications of up to 0.8 units $(896.8 \mathrm{~kg} / \mathrm{ha})$ was evident in both plant populations during most of the experiments.

Yield of cabbage was not affected by applications of $\mathrm{K}_{2} \mathrm{O}$ ci up to 1.0 unit, $(1,121 \mathrm{~kg} / \mathrm{ha})$. Absence of response to $\mathrm{K}$ applications in this soil had been shown previously by Landrau and Samuels (8) with tomato.

The fit of the fertilizer-yield equation was good; (coefficient of determination values ranged from 0.68 to 0.91 for the $\mathrm{N}$ experiments and 0.64 to 0.85 for the $\mathrm{P}$ experiments). This indicates that yields of marketable cabbage in the Coto clay at Isabela can be predicted with a fair degree of accuracy by using the equation suggested by Capó. In the case of the $\mathrm{K}$ experiments, since there was no response to $\mathrm{K}$ increments in the soil, the 
fit of the equation was not as accurate as in the $\mathrm{N}$ and $\mathrm{P}$ experiments (0.36 to 0.69). This suggests that this soil can provide the $\mathrm{K}$ needed by cabbage under the conditions of the experiments.

The usefulness of this equation is that once the $B$ and $C$ values are determined and with a reasonable estimate of $A$, based on experience and on the determination of the available nutrient in the soil by foliar analysis, the optimum economic amount of fertilizer can be estimated. The $B$ values determined from these experiments suggest that it is important to keep the $\mathrm{N}$ and $\mathrm{P}$ levels in the Coto clay close to the optimum concentration in order to obtain optimum yields of cabbage.

The results of the fit of the fertilizer-yield equation to the data suggest that to obtain maximum yields of head cabbage in the Coto clay at Isabela it is recommended that the application of $324.8,806.4$, and 996.8 $\mathrm{kg} / \mathrm{ha}$ of $\mathrm{N}, \mathrm{P}_{2} \mathrm{O}_{5}$ and $\mathrm{K}_{2} \mathrm{O}$, respectively, be made when cabbage is planted at a population density of 53,700 plants/ha. With a density of 71,700 plants/ha the corresponding amounts of $\mathrm{N}, \mathrm{P}_{2} \mathrm{O}_{5}$, and $\mathrm{K}_{2} \mathrm{O}$ determined by the equation were $336,795.2$, and $1,288 \mathrm{~kg} / \mathrm{ha}$, respectively. However to determine the optimum economic applications of these nutrients for both plant populations, other factors, such as cost of each additional unit of fertilizer and price of cabbage, have to be taken into consideration.

\section{QUALITY OF THE MARKETABLE YIELD}

Cabbage quality was measured using the criteria of solidity and average head weight. Values for cabbage firmness or solidity of 0.5 or over, and average head weight of $454 \mathrm{~g}$ or more (table 3 ) were considered indicative of marketable quality.

Values from the four $\mathrm{N}$ experiments indicated that average head weight was significantly increased following $\mathrm{N}$ applications of $112.1 \mathrm{~kg} / \mathrm{ha}$.

Data from the $\mathrm{P}$ experiments (table 3 ) indicate that average head weight was increased to a greater extent with $\mathrm{P}_{2} \mathrm{O}_{5}$ than with $\mathrm{N}$ or $\mathrm{K}$ applications. Data for the average of the experiments show the average head weight from plots with $448.4 \mathrm{~kg} \mathrm{P}_{2} \mathrm{O}_{5}$ was highly significant over plots with $112.1 \mathrm{~kg} \mathrm{P}_{2} \mathrm{O}_{5} /$ ha. However, there was no significant difference in average head weight of plots having $224.2 \mathrm{~kg}$ or more $\mathrm{P}_{2} \mathrm{O}_{5} /$ ha at the higher plant population and in plots with $448.4 \mathrm{~kg}$ or more $\mathrm{P}_{2} \mathrm{O}_{5}$ in the lower plant population.

Potash applications had no significant effect in average head weight. Table 3 also shows that there is no measurable effect of $N$, P, or $K$ on cabbage firmness.

The data summarized above indicate that cabbage quality is improved with $\mathrm{N}$ and $\mathrm{P}$ applications by increased head weight. They also suggest that firmness is a varietal feature that is not noticeably affected by the applications of different levels of $\mathrm{N}, \mathrm{P}$, and $\mathrm{K}$. 
TABLE 3.-Effect of $N, P, K$ on average head weight and firmness of head cabbage; average of four experiments

\begin{tabular}{|c|c|c|c|c|}
\hline \multirow[b]{2}{*}{ Treatments ${ }^{1}$} & \multicolumn{2}{|c|}{ Low plant population } & \multicolumn{2}{|c|}{ High plant population } \\
\hline & $\begin{array}{c}\text { Average } \\
\text { head } \\
\text { weight }\end{array}$ & Firmness & $\begin{array}{c}\text { Average } \\
\text { head } \\
\text { weight }\end{array}$ & Firmness \\
\hline & $K g$ & $G / m l$ & $K g$ & $G / m l$ \\
\hline \multicolumn{5}{|c|}{$N$ experiments } \\
\hline \multicolumn{5}{|l|}{ Units of $\mathrm{N}$} \\
\hline 0.0 & $0.52 b^{2}$ & 0.50 & $0.52 \mathrm{~b}$ & 0.51 \\
\hline .1 & $.66 \mathrm{a}$ & .53 & $.61 \mathrm{a}$ & .54 \\
\hline .2 & $.63 \mathrm{ac}$ & .54 & $.61 \mathrm{a}$ & .52 \\
\hline .4 & $.64 \mathrm{ac}$ & .53 & $.61 \mathrm{a}$ & .54 \\
\hline .6 & $.57 \mathrm{bc}$ & .54 & $.56 \mathrm{ab}$ & .54 \\
\hline .8 & $.54 \mathrm{~b}$ & .55 & $.50 \mathrm{~b}$ & .54 \\
\hline 1.0 & $.50 \mathrm{~b}$ & .55 & $.50 \mathrm{~b}$ & .55 \\
\hline \multirow{2}{*}{\multicolumn{5}{|c|}{$\mathrm{P}_{2} \mathrm{O}_{5}$ experiments }} \\
\hline Units of $\mathrm{P}_{2} \mathrm{O}_{5}$ & & & & \\
\hline 0.0 & $0.52 \mathrm{c}$ & 0.53 & $0.47 \mathrm{c}$ & 0.56 \\
\hline .1 & $.61 \mathrm{~b}$ & .54 & $.56 \mathrm{~b}$ & .55 \\
\hline .2 & $.63 \mathrm{bd}$ & .54 & $.61 \mathrm{ab}$ & .52 \\
\hline .4 & $.69 \mathrm{ad}$ & .55 & $.67 \mathrm{a}$ & .53 \\
\hline .6 & $.74 \mathrm{a}$ & .53 & $67 \mathrm{a}$ & .51 \\
\hline 8 & $.74 \mathrm{a}$ & .51 & $.68 \mathrm{a}$ & .52 \\
\hline 1.0 & $.71 \mathrm{a}$ & .54 & $.69 \mathrm{a}$ & .53 \\
\hline \multicolumn{5}{|c|}{$\mathrm{K}_{2} \mathrm{O}$ experiments } \\
\hline Units of $\mathrm{K}_{2} \mathrm{O}$ & & & & \\
\hline 0.0 & 0.62 & 0.52 & 0.61 & 0.53 \\
\hline .1 & .65 & .53 & .61 & .52 \\
\hline .2 & .63 & .54 & .61 & .52 \\
\hline .4 & .67 & .55 & .66 & .54 \\
\hline .6 & .67 & .53 & .62 & .53 \\
\hline .8 & .65 & .55 & .62 & .53 \\
\hline 1.0 & .69 & .54 & .65 & .52 \\
\hline
\end{tabular}

${ }^{1}$ When one nutrient was varied, applications of $224.2 \mathrm{~kg} / \mathrm{ha}$ were made of the other two nutrients; I unit $=1,121 \mathrm{~kg} / \mathrm{ha}$.

${ }^{2}$ Values followed by one or more letters in common do not differ significantly beyond the $1 \%$ level when compared by Duncan's multiple-range test. Absence of letters implies no significant difference.

\section{EARLINESS}

The effect of different levels of $\mathrm{N}, \mathrm{P}, \mathrm{K}$, and planting distance on maturity was measured with respect to number of heads in each of the three pickings made during each experiment. Mean percentage values from the four experiments are presented in table 4 . These values suggest that earliness is induced by the application of the three nutrients. The effect was more pronounced as a $\mathrm{P}_{2} \mathrm{O}_{5}$ response, with up to $224.2 \mathrm{~kg}$ of $\mathrm{N}$, and less defined as a $\mathrm{K}$ response. Data from $\mathrm{N}$ experiments show that maturity was retarded with applications of more than $448.4 \mathrm{~kg} / \mathrm{ha}$. 
TABLE 4.-Percentage of marketable heads in each of three pickings; mean of four experiments

\begin{tabular}{|c|c|c|c|c|c|c|}
\hline \multirow{3}{*}{ Treatments $^{1}$} & \multicolumn{6}{|c|}{ Plant population } \\
\hline & \multicolumn{3}{|c|}{$53,700 / \mathrm{ha}$} & \multicolumn{3}{|c|}{$71,700 / \mathrm{ha}$} \\
\hline & First & Second & Third & First & Second & Third \\
\hline \multicolumn{7}{|c|}{$N$ experiments } \\
\hline \multicolumn{7}{|l|}{ Units of $N$} \\
\hline 0.0 & 27 & 48 & 25 & 27 & 46 & 27 \\
\hline .1 & 51 & 43 & 6 & 46 & 46 & 8 \\
\hline .2 & 51 & 44 & 5 & 44 & 49 & 7 \\
\hline .4 & 45 & 46 & 9 & 37 & 53 & 10 \\
\hline .6 & 35 & 57 & 8 & 26 & 60 & 14 \\
\hline .8 & 25 & 59 & 16 & 16 & 71 & 13 \\
\hline 1.0 & 13 & 72 & 15 & 19 & 63 & 18 \\
\hline \multicolumn{7}{|c|}{$\mathrm{P}_{2} \mathrm{O}_{5}$ experiments } \\
\hline \multicolumn{7}{|l|}{ Units of $\mathrm{P}_{2} \mathrm{O}_{5}$} \\
\hline 0.0 & 34 & 57 & 9 & 18 & 68 & 14 \\
\hline .1 & 34 & 52 & 14 & 32 & 58 & 10 \\
\hline .2 & 51 & 44 & 5 & 44 & 49 & 7 \\
\hline .4 & 61 & 35 & 4 & 50 & 44 & 6 \\
\hline .6 & 59 & 37 & 4 & 59 & 37 & 4 \\
\hline .8 & 63 & 34 & 3 & 55 & 39 & 6 \\
\hline 1.0 & 57 & 38 & 5 & 48 & 48 & 4 \\
\hline \multicolumn{7}{|c|}{$K_{2} \mathrm{O}$ experiments } \\
\hline \multicolumn{7}{|l|}{ Units of $\mathrm{K}_{2} \mathrm{O}$} \\
\hline 0.0 & 41 & 52 & 7 & 37 & 54 & 9 \\
\hline .1 & 44 & 51 & 5 & 45 & 47 & 8 \\
\hline .2 & 51 & 44 & 5 & 44 & 49 & 7 \\
\hline .4 & 48 & 47 & 5 & 51 & 42 & 7 \\
\hline .6 & 57 & 36 & 7 & 47 & 47 & 6 \\
\hline .8 & 48 & 45 & 7 & 41 & 48 & 11 \\
\hline 1.0 & 47 & 49 & 4 & 42 & 51 & 7 \\
\hline
\end{tabular}

${ }^{1}$ When one nutrient was varied applications of $224.2 \mathrm{~kg} /$ ha were made of the other two nutrients; 1 unit $=1121 \mathrm{~kg} / \mathrm{ha}$.

Earliness was also affected by planting distances. The data indicate that higher percentage of the heads were more mature during the first picking (table 4 ) when the plants were spaced $60.96 \times 30.48 \mathrm{~cm}$.

\section{PLANTING DISTANCE}

An analysis of variance by regression eliminating blocks for the combined data demonstrated that the yield obtained at the higher plant population was highly significantly greater than that at the lower plant population.

In relation to quality, average head weight was higher when the plants were spaced $60.96 \times 30.48 \mathrm{~cm}$ (table 5). Apparently, firmness was not affected by planting distance. 


\section{PLANTING SEASON}

There is no statistical means of separating the effects of season and location on yield and quality of cabbage because the crop was grown on a different field each year. Although yields were somewhat higher during the winter, reasonable production of marketable cabbage of more than $22.00 \mathrm{t} / \mathrm{ha}$ (average of all treatments) was obtained during the four seasons of the year. It is evident that although there is some seasonal variation in yield, it is feasible to produce head cabbage of Hybrid Head Start throughout the year in this area.

\section{RESUMEN}

En experimentos que se llevaron a cabo en la Subestación Experimental de Isabela se determinó el efecto de N, P y K, usando dos densidades de siembra en cuatro estaciones del año, sobre la producción y calidad del repollo híbrido Head Start.

Los resultados de estos experimentos demostraron una señalada tendencia hacia producciones mayores cuando los niveles de $\mathrm{N}$ fluctuaban entre $0.2(224.2 \mathrm{~kg} / \mathrm{ha})$ y $0.4(448.4$ $\mathrm{kg} / \mathrm{ha}$ ) unidades. Las producciones aumentaron con aplicaciones de hasta 0.8 unidades (896.8 kg/ha) de P, y fueron mayores con densidades de aproximadamente 71,700 plantas por ha. Las aplicaciones de K no tuvieron efecto aparente sobre la producción ni el peso medio de los repollos.

Ninguna de las variables estudiadas afectó notablemente la firmeza de los repollos. La producción comercial aumentó al acortar la distancia entre hileras de 60.96 a $45.72 \mathrm{~cm}$. Esto trajo a su vez una disminución en el peso medio de los repollos.

Al aplicar la ecuación abono-rendimiento sugerida por Capó (2) a los datos de estos experimentos se obtuvo un buen ajuste en el caso de $\mathrm{N}$ y $\mathrm{P}$; se pudo constatar que se pueden predecir las producciones de repollo para los niveles de abono aplicados mediante el uso de esta ecuación.

\section{LITERATURE CITED}

1. Burleson, C. A., and Cowley, W. R., 1958. The yield, head weight, and head size of cabbage as affected by different fertilizer treatments, Rio Grande Valley Hort. Soc. J. 12: 114-18.

2. Capó, B. G., 1967. Additional evidence on the applicability of the new fertilizer-yield relation, J. Agric. Univ. P.R. 51(2): 97-120.

3. Departamento de Agxicultura del E.L.A. de Puerto Rico, Oficina de Estadísticas Agrícolas, 1976. Producción local e Importaciones de repollo 1975-76. San Juan, P.R.

4. Halsey, L. H., Beeman, J. F., Hensel, D. R., Dean, W. W., and Guzman, V. L., 1966. Influence of variety and spacing on yields of cabbage from a single harvest, Fla. State Hort. Soc. J. 194-201.

5. Hatch, R. E., Tefertiller, K. R., and Burleson, C. A., 1962. Most profitable use of nitrogen in the production of cabbage in the lower Rio Grande Valley of Texas, Prog. Rep. 2232, Texas Agric. Exp. Stn., Agric. Mech. Coll. Texas, College Station, Texas.

6. Haworth, F., 1962. The effects of different rates of application of nitrogenous fertilizer on the yield and mineral composition of spring cabbage, J. Hort. Sci. 37: 35-43.

7. Kathirgamathaiyah, S., 1965. Fertilizer experiments on cabbage and bean in the Upcountry, Trop. Agric. Ceylon, 121: 151-5.

8. Landrau, P., Jr., and Samuels, G., 1955. Influence of fertilizer on the yield of the Plamar variety of tomatoes on a Coto clay, J. Agric. Univ. P.R. 39(2): 77-83.

9. Lugo-López, M. A., and Rivera, L. H., 1976. Taxonomic classification of the soils of Puerto Rico, Agric. Exp. Stn. Univ. P.R., Bull. 245. 
10. Pearson, O. H., 1931. Methods for determining the solidity of cabbage heads, Hilgardia, 5(11): 383-93, Univ. Calif. Printing Office, Berkley, Calif., U.S.A.

11. Vittum, M. T., and Peck, N. H., 1956. Response of cabbage to irrigation, fertility level and spacing, N.Y, State Agric. Exp. Stn., Cornell Univ. Bull. 777, Geneva, N.Y.

12. Webster, A. B., 1969. Manuring and spacing experiments on vegetables, N.Z.J. Agric. Res. 12: 381-416. 